\title{
Coccolith moulds in sedimentary organic matter and their use in palynofacies analysis
}

\author{
D. J. BATTEN \\ Department of Geology and Mineralogy, Marischal College, Aberdeen University, Aberdeen AB9 1AS, Scotland
}

\begin{abstract}
Imprints of coccoliths can be expected on palynomorphs and phytoclasts in Rhaetian and younger palynofacies. They resemble the hollows left by spheroidal pyrite but may commonly be distinguished on the basis of shape and by occasional marks which reflect the arrangement of the calcite laths of which they were composed. Monospecific blooms are suggested when they are abundant and their size and form is more or less constant. Those which are larger than average and bear arcuate grooves subparallel to their margins may indicate the former presence of coccospheres. The occurrence of coccolith moulds in pre-Quaternary palynofacies both indicates marine influence on the environment of deposition and provides evidence for the affinity of amorphous organic matter in problematical preparations which are swamped with this material and contain few palynomorphs.
\end{abstract}

\section{INTRODUCTION}

Palynomorphs, cuticles and amorphous substances are among the various kinds of acid-resistant organic matter (kerogen) which frequently bear structures indicating the former presence of minerals and other microfossils in intimate association. Those left by pyrite are the most abundant and widely recognised. The identification of other minerals which leave their mark on phytoclasts is more difficult because, unlike pyrite, they rarely survive palynological processing; inferences can, however, be made from the mineralogical composition of the untreated sediment. Some patterns of degradation resulting from microbial activity and fungal attack resemble mineral impressions but are normally distinguishable on structural grounds. Other compression features include moulds of calcareous and siliceous microfossils and outlines of some of the more robust palynomorphs. Among the most common are imprints of coccoliths, but to judge from the literature palynologists have not paid much attention to them. It seems likely that they have seldom been recognised.

Modern coccolithophores are largely planktonic marine organisms. Although characteristically oceanic, some inhabit littoral, lagoonal and estuarine realms and a few are found in fresh water. Near-shore and estuarine forms tolerate a range of salinities but the sedimentary environments in these areas are often unfavourable for their preservation. Together with more limited distributions, this accounts for the scarcity of calcareous nannofossils in Mesozoic and Tertiary sediments deposited under such conditions (Crux \& Lord, 1982). The few freshwater nannoplankton known (Tappan, 1980) are much less common and do not appear to have a fossil record.
The identification of coccolith moulds in a palynological preparation can, therefore, provide a useful indication of marine influence through pre-Quaternary sequences that comprise sediments that were laid down in variably saline to freshwater environments. They may also suggest a marine origin for amorphous matter of otherwise uncertain affinity which accumulated in anoxic conditions. Their importance in palynofacies analysis should not be overlooked.

Separation of nannoplankton imprints from relic structures of different origins is not always easy however, and confirmation under scanning electron microscopy may be necessary. Those produced by pyrite and other minerals and microfossils are thus briefly reviewed prior to further discussion of coccolith moulds.

\section{PYRITE AND ITS RELIC STRUCTURES}

Pyrite typically occurs in unoxidised palynological preparations as very small $(<5 \mu \mathrm{m})$ angular crystals and spheroids (Pl. 1, figs. 1, 2) and as larger bodies up to $60 \mu \mathrm{m}$ or more in maximum diameter (Pl. 1, figs. 2-4). Its mode of formation has been considered by many authors (e.g. Love, 1958, 1962, 1963, 1964; Neves \& Sullivan, 1964; Schopf et al., 1965; Berner, 1970; Hudson, 1978; Howarth, 1979; Curtis, 1980; Morris, 1980; Hartman, 1981). Bacterially related sulphate reduction in anoxic conditions is thought to be largely responsible. This may occur in a variety of aquatic environments mainly in the marine realm, within the water itself and at or below the sediment-water interface (Berner, 1964, 1978; Goldhaber \& Kaplan, 1975; Coleman et al., 1979). The mineral is typically abundant in oil shales and hence in association with the amorphous detritus which characterises their organic content. 
Although varying in morphology (Combaz, 1980; Batten, 1983) and origin, much of the latter is likely to comprise bacterially altered, and decomposition products of, algae. Aizenshtat et al . (1973) and Lyons \& Gaudette (1979) have suggested that organic matter rich in algal remains is more readily degraded by sediment microbes than that derived from land plants. Depending on the form of the pyrite, the relic structures may be angular, reflecting crystal faces or rounded, indicating derivation from spheroids (Pl. 1, figs. 5, 6; PI. 2, fig. 1).

\section{OTHER STRUCTURES}

The former presence of other minerals which are normally dissolved during sample preparation may also be indicated by relic structures (Pl. 2, figs. 2, 4; see also Combaz, 1980, pl. 3, 6, fig. 8) but as Robbins \& Traverse (1980) have pointed out, it is only possible to speculate on their origin. The amount of guesswork required is, however, reduced if the mineralogy of the rock specimen is known. Some of the angular shapes that typify pyrite can also be produced by other minerals such as calcite, fluorite and halite. Similarly, small rounded structures (c. $5 \mu \mathrm{m}$ or less in diameter) may be attributable not only to pyrite but also to microbial activity (e.g. Elsik, 1971; Robbins \& Traverse, 1980) and the removal of solid granules from granular amorphous matter (Pl. 2, fig. 3). They often become more pronounced with increasing thermal maturation (Pl. 2, fig. 4; cf. Batten, 1982a). Larger impressions can indicate the former presence of a variety of microfossils including centric diatoms, foraminifers and relatively robust palynomorphs such as tasmanitids and leiospheres. These are most clearly discernible in finely granular masses and flakes of amorphous organic matter.

\section{COCCOLITH MOULDS}

Various structures attributable to calcareous nannoplankton may be encountered in palynological preparations of Rhaetian and younger samples. Their skeletal elements are preserved in abundance in thin organic-rich laminae within calcareous sequences (Gallois, 1976, 1978; Noël \& Manivit, 1978; Irwin, 1979, 1980; Tyson, 1979; Tyson et al., 1979). In the Kimmeridgian of southern England, these show microlaminations of alternating dark organic and light coccolith-rich layers. An intimate association of coccoliths with organic matter has been demonstrated by nannoplankton workers using scanning electron microscopy (Noël, 1972; Busson \& Noël, 1972; Noël \& Manivit, 1978).

The majority of coccolithophores leave small circular to oval impressions and perforations. These were observed by Downie (1957) in the walls of Kimmeridgian dinoflagellate cysts but have since received little attention, and their value in palynofacies analysis has not been considered previously. This is perhaps because their separation from relic structures produced by spheroidal (framboidal) pyrite is not straightforward (cf. Pl. 2, figs. 1, 3), and the possibility of their occurrence can be overlooked. I have, for example, previously illustrated a flake of amorphous material purporting to show (largely spheroidal) pyrite relic structures (Batten, $1982 \mathrm{~b}$, pl. 2, fig. 3); although a few of the shapes do indicate the former presence of this mineral, most are, in fact, coccolith moulds (see also Pl. 2, fig. 5 herein). Some of the amorphous masses illustrated by Combaz (1980, pl. 3.6, fig. 3 and pl. 3. 10, fig. 4) appear to show similar imprints.

The presence of markings within the moulds reflecting the arrangement of the calcite laths of which they were composed confirms a coccolith origin, but these are

\section{Explanation of Plate 1}

Fig. 1. Amorphous organic matter with an abundance of pyrite in association. Preparation DB3045.1, Lower Jurassic, England Finder Reference (EFR) N44/3 (×150).

Fig. 2. Dispersed spheroidal and angular crystals of pyrite dominate the general aspect of this field of view. Preparation DB3049.1, Jurassic, EFR F34/2 (×150).

Fig. 3. Palynomorphs infilled with pyrite. Preparation DB3145.1, Upper Cretaceous, EFR M45/0 ( $\times 150)$.

Fig. 4. Rather irregular framboid and a mass of spheroidal pyrite infilling a dinoflagellate cyst. Preparation DB3269.2, Cretaceous, EFR M22/3 ( $\times 500)$.

Fig. 5. Pyrite relic structures in a mass of sphaeromorph acritarchs. Preparation DB2235.2, Silurian, EFR 045/1 $(\times 500)$.

Fig. 6. Flake of pellicular-amorphous organic matter showing pyrite relic structures. Preparation DB2235.2, Silurian, EFR K39/1 (×500). 


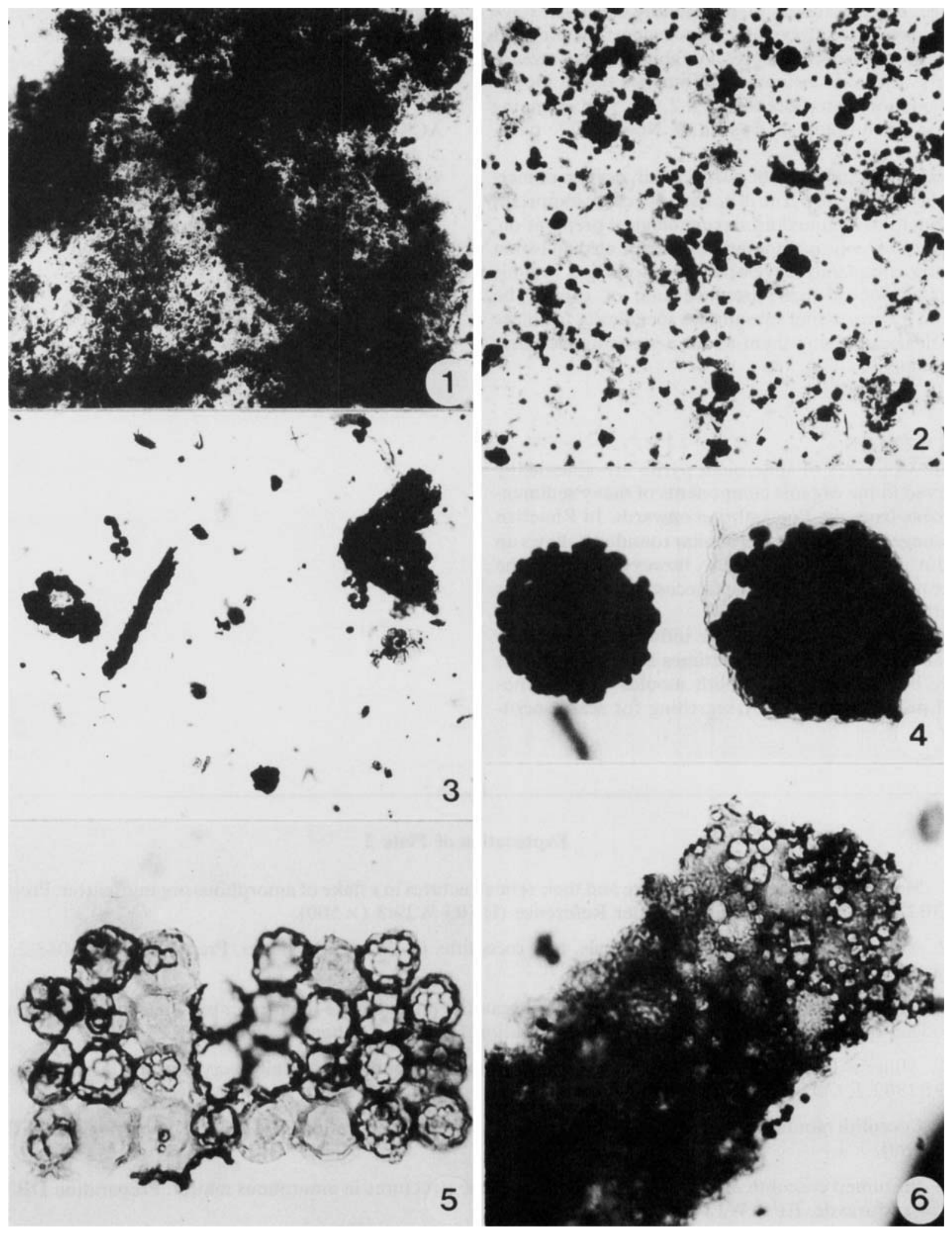


normally only discernible when subjected to scanning electron microscopy. Cavities which are larger than average (cf. Pl. 2, figs. 6, 7), particularly those that show marginal arcuate grooves, may suggest a previous association with coccospheres. An abundance of moulds of fairly constant size and shape implies that a monospecific bloom is represented (Pl. 2, fig. 5; cf. scanning electron micrograph in Busson \& Noël, 1972, pl. 3, fig. 3).

Coccolith origins may be suspected if, despite numerous relic structures, pyrite is not an especially important component of an unoxidised palynological preparation. Rarely, calcareous nannoplankton escape acid digestion by being completely enveloped in amorphous organic matter. Proof of their presence can, of course, be checked by processing subsamples specifically for these fossils and examining them under a scanning electron microscope.

\section{CONCLUSION}

Relic structures of spheroidal pyrite are abundantly preserved in the organic components of many sedimentary rocks from the Precambrian onwards. In Rhaetian and younger material, rather similar rounded hollows up to about $15 \mu \mathrm{m}$ in diameter may, however, indicate the former presence of coccoliths. Coccosphere impressions are rather larger.

The determination of marine influence on a depositional environment can sometimes be achieved more rapidly by recognising coccolith moulds in a palynological preparation than by searching for scarce acrit- archs, foraminiferal linings and other marine indicators; indeed, they may provide the only positive evidence in some palynofacies. At the same time, discrimination between marine and non-marine amorphous organic matter in pre-Quaternary preparations is commonly facilitated.

\section{ACKNOWLEDGEMENTS}

All the figures are from palynological preparations of samples provided by British Petroleum plc. I thank Dr. J. F. Raynaud (Société Nationale Elf Aquitaine) for discussion and Mrs. L. Morrison for technical assistance.

\section{Explanation of Plate 2}

Fig. 1. Mostly spheroidal bodies of pyrite and their relic structures in a flake of amorphous organic matter. Preparation DB2235.2, Silurian, England Finder Reference (EFR) W29/3 ( $\times 500)$.

Fig. 2. Moulds of pyrite and other minerals, and coccoliths in amorphous tissue. Preparation DB3043.2, Lower Jurassic, EFR 031/2 ( $\times 500)$.

Fig. 3. Granular amorphous mass. One or two of the cavities may indicate the former presence of other granules dislodged during palynological processing. Preparation DB2905.2, Rhaetian, EFR J33/3 ( $\times 500)$.

Fig. 4. Mineral imprints in structurally degraded tasmanitids from a thermally very mature facies. Preparation DB2882.2, Carboniferous, EFR E37/2 $(\times 150)$.

Fig. 5. Coccolith moulds in a flake of amorphous organic matter. Preparation DB1323.1, Kimmeridgian, EFR P52/2 $(\times 500)$.

Fig. 6. Presumed coccolith and possibly foraminiferal relic structures in amorphous matter. Preparation DB3058.2, Lower Jurassic, EFR W22/2 (×500).

Fig. 7. Part of a cluster of leiospheres showing probable coccolith and other outlines in their walls. Preparation DB3043.2, Lower Jurassic, EFR N30/3 (×500). 


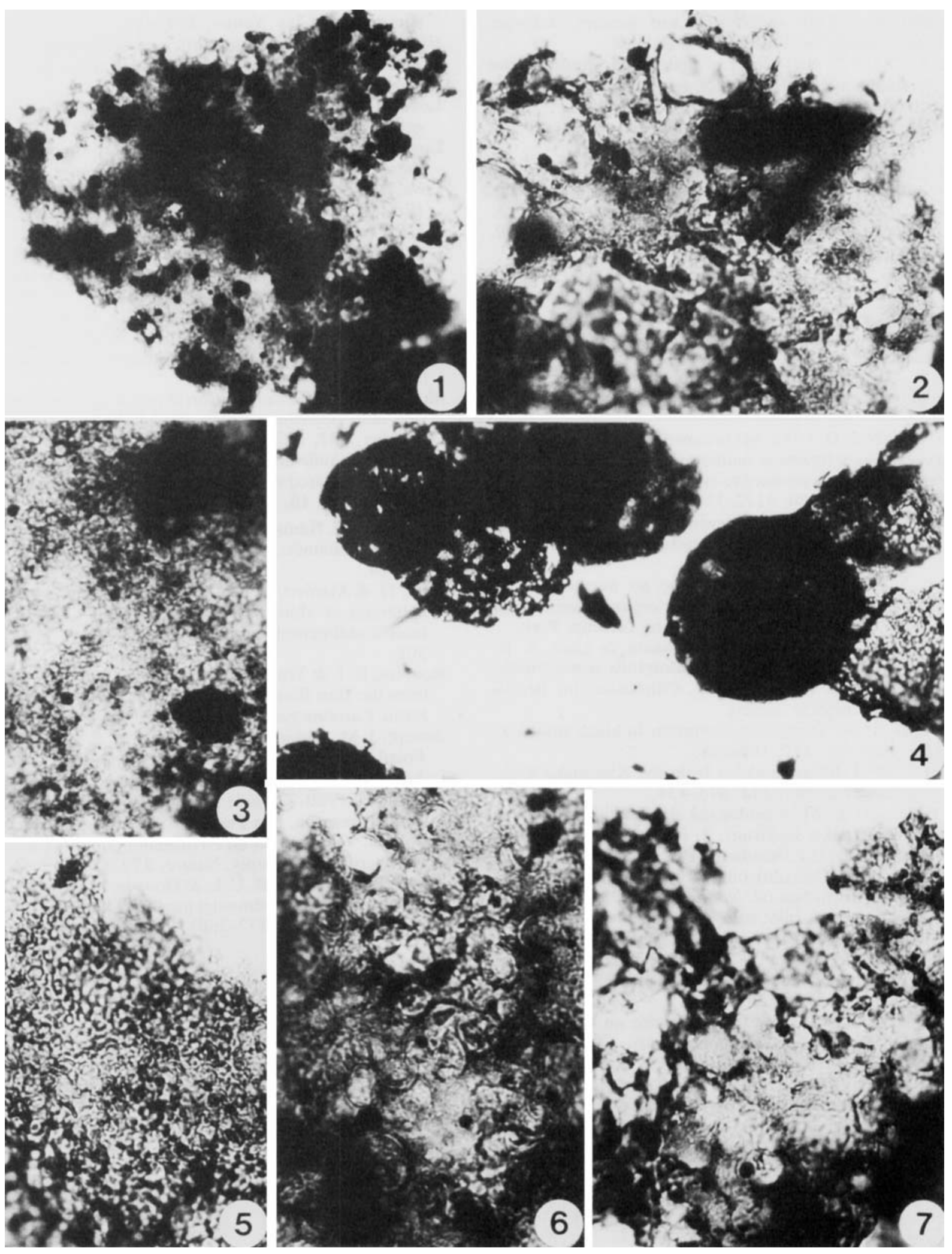




\section{REFERENCES}

Aizenshtat, Z., Baedecker, M. J. \& Kaplan, I. R. 1973. Distribution and diagenesis of organic compounds in JOIDES sediment from Gulf of Mexico and western Atlantic. Geochim. cosmochim. Acta, 37, 1881-1898.

Batten, D. J. 1982a. Palynology of shales associated with the Kap Washington Group Volcanics, central North Greenland. Rapp. Grønlands geol. Unders., 108, 15-23.

Batten, D. J. 1982b. Palynofacies, palaeoenvironments and petroleum. J. micropalaeontol., 1, 107-114.

Batten, D. J. 1983. Identification of amorphous sedimentary organic matter by transmitted light microscopy. In Brooks, J. (Ed.), Petroleum geochemistry and exploration of Europe, Spec. Publ. geol. Soc. London, 11, 275-287, Blackwell, Oxford.

Berner, R. A. 1964. An idealized model of dissolved sulphate distribution in recent sediments. Geochim. cosmochim. Acta, 28, 1497-1503.

Berner, R. A. 1970 . Sedimentary pyrite formation.Am. J.Sci., 268, 1-23.

Berner, R. A. 1978. Sulphate reduction and the rate of deposition of marine sediments. Earth Planet. Sci. Lett., 37, 492. 498.

Busson, G. \& Nol, D. 1972. Sur la constitution et la genèse de divers sédiments finement feuilletés ("laminites"), à alternances de calcaire et de matière organique ou argileuse. C.R. Acad.Sci.Paris, D, 274, 3172-3175.

Coleman, M. L., Curtis, C. D. \& Irwin, H. 1979. Rate of burial important for source and reservoir potential. World Oil, 188, 83-92.

Combaz, A. 1980. Les kérogènes vue au microscope. In Durand, B. (Ed.), Kerogen: insoluble organic matter from sedimentary rocks, pp. 55-111, Editions Technip, Paris.

Crux, J. A. \& Lord, A. R. 1982. Discussion. In Lord, A. R. (Ed.), A stratigraphical index of calcareous nannofossils, pp. 168-173, Ellis Horwood Ltd., Chichester, for British Micropalaeontological Society.

Curtis, C. D. 1980. Diagenetic alteration in black shales. $J$, geol. Soc. London, 137, 189-194.

Downie, C. 1957. Microplankton from the Kimeridge Clay. Q.J. geol. Soc. London, 112, 413-434.

Elsik, W. C. 1971. Microbiological degradation of sporopollenin. In Brooks, J., Grant, P. R. et al. (Eds.), Sporopollenin, pp. 480-511, Academic Press, London.

Gallois, R. W. 1976. Coccolith blooms in the Kimmeridge Clay and origin of North Sea oil. Nature, 259, 473-475.

Gallois, R. W. 1978. A pilot study of oil shale occurrences in the Kimmeridge Clay. Rep. Inst. Geol. Sci., No. 78/13,26 pp.

Goldhaber, M. B. \& Kaplan, I. R. 1975. Controls and consequences of sulphate reduction rates in recent marine sediments. Soil Sci., 119, 42-55.

Hartman, C. M. 1981. The effect of pyrite on the tracheid structure of Drepanophycus spinaeformis, a long-ranging Devonian lycopod. Rev. Paleobot. Palynol., 32, 239-255.

Howarth, R. W. 1979. Pyrite: its rapid formation in a salt marsh and its importance in ecosystem metabolism. Science, 203, 49-51.
Hudson, J. D. 1978. Pyrite in ammonite shells and in shales. N. Jb. Geol. Paläont. Abh., 157, 190-193.

Irwin, H. 1979. On an environmental model for the type Kimmeridge Clay. Nature, 279, 819.

Irwin, H. 1980. Early diagenetic carbonate precipitation and pore fluid migration in the Kimmeridge Clay of Dorset, England. Sedimentology, 27, 577-591.

Love, L. G. 1958. Micro-organisms and the presence of syngenetic pyrite. Q.J. geol. Soc. London, 113, 429-440.

Love, L. G. 1962. Further studies on micro-organisms and the presence of syngenetic pyrite. Palaeontology, 5, 444-459.

Love, L. G. 1963. Pyrite spheres in sediments. In Jensen, M. L. (Ed.), The biogeochemistry of the sulphur isotopes, pp. 121143, Yale University, New Haven.

Love, L. G. 1964. Early diagenetic pyrite in fine-grained sediments and the genesis of sulphide ores. In Amstutz, G. G. (Ed.), Sedimentology and ore genesis, Developments in Sedimentology, 2, pp. 11-17, Elsevier, Amsterdam.

Lyons, W. B. \& Gaudette, H. E. 1979. Sulphate reduction and the nature of organic matter in estuarine sediments. Organic Geochemistry, 1, 151-155.

Morris, K. A. 1980. Comparison of major sequences of organicrich mud deposition in the British Jurassic. J. geol. Soc. London, 137, 157-170.

Neves, R. \& Sullivan, H. J. 1964. Modification of fossil spore exines associated with the presence of pyrite crystals. Micropaleontology, 10, 443-452.

Noël, D. 1972. Nannofossils calcaires de sédiments jurassiques finement laminés. Bull. Mus. national Hist. Nat., Ser. 3, 75, 95-124.

Noël, D. \& Manivit, H. 1978. Nannofaciès de "black shales" aptiennes et albiennes d'Atlantique sud (legs 36 et 40 ). Intérêt sédimentologique. Bull. Soc. géol. France, 20, 491502.

Robbins, E. I. \& Traverse, A. 1980. Degraded palynomorphs from the Dan River (North Carolina) - Danville (Virginia) Basin. Carolina geol. Soc. Field Trip Guidebook, B-X-1-11.

Schopf, J. M., Ehlers, E. G., Stiles, D. V. \& Birle, J. D. 1965. Fossil iron bacteria preserved in pyrite. Proc. Am. Philos. Soc., 109, 288-308.

Tappan, H. 1980. The paleobiology of plant protists, 1028 pp., W. H. Freeman, San Francisco.

Tyson, R. V. 1979. On an environmental model for the type Kimmeridge Clay-reply. Nature, 279, 819.

Tyson, R. V., Wilson, R. C. L. \& Downie, C. 1979. A stratified water column environmental model for the type Kimmeridge Clay. Nature, 277, 377-380. 